\title{
农田水利工程高效节水灌溉研究
}

卢禄

阿克苏地区水利水电勘测设计院有限公司

DOI:10.32629/hwr.v3i8.2346

[摘 要] 农田水利工程高效节水灌溉的运用, 大大提高了农业灌溉的效率, 同时节约了水资源, 因此应大力推广和使用农田水 利工程高效节水灌溉技术。基于此, 本文主要分析了农田水利高效节水灌溉技术应用的重要性、现状, 探究了农田水利工程节 水灌溉技术实施要点,并进行了案例分析。

[关键词] 农田水利工程; 高效节水; 灌溉

在我国农村经济发展中, 农田水利工程发挥了重要的推 动作用。由于水资源量少的影响, 在农田灌溉过程中, 应积极 使用高效节水灌溉技术, 从而满足农业生产与人们的饮水需 求, 进而增加农民的经济效益。

\section{1 农田水利高效节水灌溉技术应用的重要性}

所谓的农田水利工程的节水灌溉, 是指对传统灌溉技术 进行创新, 不仅满足农作物生长的用水需求, 也能更好地节 约水资源, 从而达到水资源利用最大化的目的。众所周知, 我国是一个水资源人均占有量较少的国家, 同时也是一个农 业大国, 如何在农业生产中高效利用水资源, 是我国农业发 展中的重要问题。为了解决这一问题, 就需要积极发展农田 水利工程节水灌溉技术, 从而提高水资源的应用效率; 同时, 还要建设农田节水灌溉的相关设施, 根据区域农业的发展情 况, 科学合理地制定灌溉方案, 促进农作物的生长, 从而为农 民创造更好的效益 ${ }^{[1]}$ 。

\section{2 农田水利工程高效节水灌溉现状}

2. 1 管理力度有待提高

要想实现农田水利工程的发展, 则需要高度重视高效节 水灌溉建设。但现阶段我国在高效节水灌溉建设方面的管理 力度不足, 导致农村农田水利工程高效节水灌溉建设不能正 常运行, 最终造成节水效果不理想, 使得农业生产与预期目标 存在一定的差距。因此, 要制定严格的高效节水灌溉制度, 并将 该制度在农田水利工程开展的各个阶段进行有效落实, 并安排 专业的管理人员进行管理, 从而保障节水灌溉的有效运行。

\section{2 设计不合理}

对工程进行科学合理地规划, 能够在一定程度上保障工程 建设的顺利开展, 农田水利工程亦是如此。但在农田水利工程 实际设计过程中, 多数设计人员设计水平不高, 且对设计要求 较低, 导致设计出现不合理现象。例如, 未对工程区域土壤进行 详细分析, 导致植物种植结构不够合理。工程现场的实际考察是 高效节能灌溉的重要部分, 但多数设计人员队工程区域调研不 重视, 只凭自身经验进行设计, 使得设计与实际不符, 导致许多 不合理的情况发生, 阻碍了农田水利工程高效节水灌溉的顺利 进行。因此, 设计人员在农田水利工程施工前, 要到现场进行实 地考察, 从而保障设计的质量, 进而满足高效节水灌溉的要求。

\section{3区域种植结构不协调}

就农田水利工程高效节水灌溉来说, 其是否能正常运行 受农田种植结构合理性的影响, 因此要深入分析开展节水灌 溉区域的农田种植结构的合理性。目前, 我国农田种植结构 还延续传统的种植理念, 相应的种植结构也未发生改变。但 新时代的高效节水灌溉要求种植结构应进行优化更新, 如果 农民不合理规划农田种植结构, 将难以充分发挥农田水利工 程高效节水灌溉的作用, 不利于农民经济的发展。因此, 要大 力推广和宣传农田水利工程高效节水灌溉的优势, 让更多农 民改变传统的种植结构, 从而充分发挥高效节水灌溉的作用, 进而创造更多的经济价值。

\section{3 农田水利工程节水灌溉技术实施要点}

3. 1 做好前期的准备工作

区域不同相应的水资源含量不同, 农作物的种植状况也 不同, 所以, 在高效节水灌溉工程建设之前, 需要做好前期的 一系列准备工作。此处的准备工作主要包括区域的勘察与调 研工作, 对区域的情况进行实地考察, 获取区域的水文地质、 农作物种类等资料, 为高效节水灌溉设计提供参考依据, 提 高设计的质量, 从而更好地指导农田水利高效节水灌溉工程 的施工建设, 进而推动当地农业的发展。

3. 2 引入和应用新型的节水灌溉技术

在我国科学技术不断进步与发展的背景下, 农业技术得 到了更新与发展, 特别是节水灌溉技术的发展, 极大程度上 提高了水资源的利用率, 促进了农业的发展。节水灌溉技术 的应用, 在农田水利节水灌溉工程建设中是不可缺少的, 而 新型节水灌溉技术的应用更能提高灌溉效率和质量。因此, 农田水利节水灌溉工程建设中, 要积极引入并应用新型的节 水灌溉技术, 比如基于 $3 S$ 技术的高效节水灌溉技术、智能控 制技术等。在实际的应用过程中, 要结合区域的实际情况, 选择适宜的节水灌溉技术, 从而发挥技术的最大效能。

3. 3加大农田水利高效节水灌溉工程建设力度

建设高效节水灌溉工程是节水灌溉工程大力发展的重要 内容之一, 因此, 要加大节水灌溉工程的建设力度。但在实际 的建设过程中, 要注意以下几点内容: 合理选择工程建设地址, 优先选择经济比较发达地区、种植种类比较多的区域等; 工程 
施工阶段, 施工人员要严格按照设计方案进行施工, 并采用先 进的施工技术施工, 从而提高施工质量和水平 ${ }^{[2]}$ 。另外, 还应注 意信息技术的应用, 从而提高工程建设的信息化、自动化水平, 从而提升工程的整体质量, 进而发挥更好地节水灌溉效果。

3.4 对节水灌溉工程进行科学管理

管理是工程建设的重要内容, 也是提高工程建设质量的 重要手段, 因此重视管理工作, 并保障管理工作的科学性、有 效性, 从而保障工程施工质量。在农田水利高效节水灌溉工 程建设中, 要加强管理工作, 并积极听取相关专家的意见和 建议, 为节水灌溉工程的建设提供保障。同时, 要结合区域实 际情况, 制定合理的施工方案并实施。工程施工过程中, 要采 用现代化的管理手段, 运用先进的技术对农作物的生长情况 进行检测, 根据检测数据信息来对管理工作进行合理调整, 从而提升管理的质量。

\section{4 农田水利工程高效节水灌溉实例分析}

以阿瓦提县南疆田间高效节水项目工程为例, 对农田水 利工程高效节水灌溉进行研究。

\section{1 工程概况}

阿瓦提县南疆田间高效节水项目工程涉及的地区有塔木 托格拉克镇、丰收二场及英艾日克镇、拜什艾日克镇, 灌溉总 面积为 5.37 万亩。本工程共建立了 52 个地表水加压滴灌系统, 新建首部共45处。阿瓦提县位于新疆维吾尔自治区中西部, 塔 里木盆地西北边缘, 全境均属平原, 县内各乡、镇、场均有公路 相通, 交通状况良好。该高效节水灌溉项目的建设, 将大大提高 三个城镇的农业灌溉效率, 促进这三个区域的农业发展。

\section{2 高效节水灌溉工程的建设现状}

截至 2017 年底, 阿瓦提县全灌区耕地面积为 174.55 万 亩。该地区的主要作物有小麦、棉花、其他种植、林果业等, 相对应的面积为 15.5 万亩、 99.02 万亩 (常规灌面积为 36.52 万亩、滴灌面积为 62.5 万亩)、 8.22 万亩、 34.76 万亩 (常规 灌面积为 29.5 万亩、滴灌面积为 5.26 万亩)。

\section{3水源工程的布置与建设}

就水源工程来说, 主要包括三项工程, 即引水闸工程、引 水渠工程、沉沙池工程。具体来说, 引水闸工程, 将引水闸设 置在水源支渠, 将 $30 \mathrm{~cm}$ 厚的混凝土板嵌入平板钢闸门, 用来控 制水位及流量; 引水渠工程, 引水渠上游接引水闸, 下游接沉 沙池; 沉沙池工程, 沉沙池主要包括三部分, 即进水区、沉淀 区和出水区, 其底部宽度与长度由现状地形条件具体确定。

4. 4 管网工程的设置与建设

管网工程主要包括两部分, 即系统首部工程、管道工程。 具体来说, 系统首部设置在水源之后、总干管之前, 将各项设备 布置在首部设备房内; 管道工程, 主要采用两种布置形式, 即叉 式布置和梳式布置, 配套设备包括闸阀、镇墩、量测设备等。

\section{5 灌溉制度}

本次项目根据新疆维吾尔自治区水利厅颁布的相关灌 溉用水指标, 结合项目区作物现状不同灌溉方式下的用水定 额、灌水时间及本区各项参数进行计算, 并制定了灌溉制度
表。其中棉花的灌溉制度表, 如下表1所示:

表1 项目区棉花灌溉制度表

\begin{tabular}{|c|c|c|c|c|c|c|}
\hline \multirow{2}{*}{ 作物名称 } & \multirow{2}{*}{ 生育阶段 } & \multirow{2}{*}{ 灌水次数 } & \multicolumn{2}{|c|}{ 灌水时间 } & \multirow{2}{*}{\multicolumn{2}{|c|}{$\begin{array}{l}\text { 灌水定额 }\left(\mathrm{m}^{3} /\right. \\
\text { 亩) }\end{array}$}} \\
\hline & & & 始 & 终 & & \\
\hline \multirow{5}{*}{ 棉花 (常规灌) } & 播前 & 1 & 2 月 21 日 & 3 月 10 日 & 80 & \multirow{5}{*}{360} \\
\hline & 现蕾 & 2 & 6月 11 日 & 6 月 20 日 & 70 & \\
\hline & 花期 & 3 & 7 月 11 日 & 7 月 20 日 & 70 & \\
\hline & 结铃 & 4 & 8月 11 日 & 8月 20 日 & 70 & \\
\hline & 吐絮期 & 5 & 8 月 26 日 & 9 月 5 日 & 70 & \\
\hline \multirow{12}{*}{ 棉花 (滴灌) } & 播前 & 1 & 2 月 21 日 & 3 月 10 日 & 100 & \multirow{12}{*}{353} \\
\hline & 一水 & 2 & 6 月 1 日 & 6月 6 日 & 23 & \\
\hline & 二水 & 3 & 6月9日 & 6 月 14 日 & 23 & \\
\hline & 三水 & 4 & 6 月 17 日 & 6 月 22 日 & 23 & \\
\hline & 四水 & 5 & 6 月 25 日 & 6 月 30 日 & 23 & \\
\hline & 五水 & 6 & 7月 3 日 & 7月 8日 & 23 & \\
\hline & 六水 & 7 & 7 月 11 日 & 7 月 16 日 & 23 & \\
\hline & 七水 & 8 & 7 月 19 日 & 7 月 24 日 & 23 & \\
\hline & 八水 & 9 & 7 月 24 日 & 7 月 30 日 & 23 & \\
\hline & 九水 & 10 & 8 月 1 日 & 8 月 6 日 & 23 & \\
\hline & 十水 & 11 & 8 月 11 日 & 8 月 16 日 & 23 & \\
\hline & 十一水 & 12 & 8 月 26 日 & 8月 31 日 & 23 & \\
\hline
\end{tabular}

4. 6 高效节水灌溉工程施工

4. 6.1 首部沉沙池工程

首先是土方开挖, 严格按设计断面要求, 利用机械进行 沉沙池土方开挖, 酒水压实刮平。其次是铺设砂砾石垫层, 通过自卸汽车将砂砾石运至现场, 在挖填密实、平整的土基 上回填砂砾石。最后是混凝土工程施工, 混凝土板在指定预 制场进行预制, 后进行混凝土浇筑缝隙; 现浇混凝土封顶板 按照备料、立模、浇筑、振捣、压光、养护、脱模的顺序施 工 $^{[3]}$ 。通过各个部分的有效施工, 最终形成首部沉沙池。

\subsection{2 滴灌管网工程}

滴灌节水施工可分首部系统、地埋管道系统、地面滴灌系 统三部分。其施工流程如下: 预备材料、模具 $\rightarrow$ 施工放线 $\rightarrow$ 机 械开挖管沟 $\rightarrow$ 人工整理管沟 $\rightarrow$ 布管 $\rightarrow$ 管道及管件安装 $\rightarrow$ 第一 次人工填土定位至管顶以上 $40 \sim 50 \mathrm{~cm} \rightarrow$ 浇筑砤镇墩 $\rightarrow$ 筑工作 井、渗井 $\rightarrow$ 冲洗管道、系统试运行 $\rightarrow$ 压力试验 $\rightarrow$ 机械填土 $\rightarrow$ 验收。 按照流程, 结合相关技术进行施工, 从而保障滴管网工程的质量。

\section{5 结束语}

总而言之, 农田水利工程高效节水灌溉能够提高水资源 的利用率, 同时能够满足农作物的用水需求, 促进农作物的 成长。因此, 要建设农田水利工程, 采用高效节水灌溉技术, 从而实现水资源的有效利用, 发挥工程的价值, 进而推动农 业的生产与发展。

\section{[参考文献]}

[1]余昆.农田水利工程高效节水灌溉研究 [J].江西农 业,2018(6):67.

[2]张文国.农田水利工程高效节水灌溉发展思路研究 [J].甘肃农业,2017(6):55.

[3]李娇燕, 王恩义.农田水利工程高效节水灌溉技术要 点之研究 [J].建筑工程技术与设计,2017(3):19.

\section{作者简介：}

卢禄(1984--),男,新疆石河子市人,汉族,本科学历,中级 工程师,研究方向：农田水利,防洪工程,水工建筑物；从事工 作：水利工程设计 